\title{
Do intra-articular pathologies accompanying symptomatic acromioclavicular joint degeneration vary across age groups?
}

\author{
Semptomatik akromioklaviküler eklem dejenerasyonuna eşlik eden eklem içi patolojiler \\ yaş gruplarına göre farklılık gösterir mi?
}

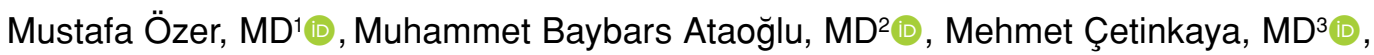

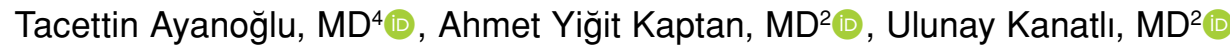 \\ ${ }^{1}$ Department of Orthopedics and Traumatology, Necmettin Erbakan University Meram Faculty of Medicine, Konya, Turkey \\ ${ }^{2}$ Department of Orthopedics and Traumatology, Gazi University School of Medicine, Ankara, Turkey \\ ${ }^{3}$ Department of Orthopedics and Traumatology, Erzincan University Mengücek Gazi Training and Research Hospital, Erzincan, Turkey \\ ${ }^{4}$ Department of Orthopedics and Traumatology, Yozgat City Hospital, Yozgat, Turkey
}

\begin{abstract}
Objectives: This study aims to evaluate the accompanying intraarticular pathologies in patients who underwent arthroscopic distal clavicle resection (DCR) for symptomatic acromioclavicular (AC) joint degeneration based on age groups and to reveal which additional pathologies should be considered across different age groups during physical examination of patients suspected of AC joint degeneration.

Patients and methods: The study included 156 patients (55 males, 101 females; mean age $57.2 \pm 10.0$ years; range, 35 to 80 years) who underwent arthroscopic DCR between January 2006 and December 2017 and had at least one clinical positive test for AC joint degeneration during the preoperative physical examination. The patients were divided into three groups as those aged $<50$ years (group 1), between $50-65$ years (group 2), and $>65$ years (group 3). The concomitant intra-articular pathologies were evaluated across different age groups and compared between the groups.

Results: Concomitant intra-articular pathologies were detected in $117(75 \%)$ of a total of 156 patients. Additional pathology rate increased with increasing age $(\mathrm{p}=0.002)$. More than one concomitant intraarticular pathologies were detected in 37 patients $(23.7 \%)$. This rate increased with increasing age $(\mathrm{p}=0.002)$. The number of patients with superior labrum anterior posterior (SLAP) lesion as the only additional pathology was $33(21.2 \%)$. This rate decreased with increasing age $(\mathrm{p}=0.015)$. In group 1 , the rate of concomitant SLAP lesion was $44.1 \%$.

Conclusion: The high incidence of intra-articular pathologies accompanying symptomatic $\mathrm{AC}$ joint degeneration raises the importance of careful physical examination, detailed imaging, and arthroscopic surgery to obtain good results in patients scheduled for DCR. The frequency of $\mathrm{AC}$ joint degeneration and concomitant SLAP lesions, particularly in younger patients, should be considered during clinical examinations.
\end{abstract}

Keywords: Acromioclavicular joint, arthroscopy, distal clavicle resection, rotator cuff tear, superior labrum anterior posterior lesion.
$\ddot{O} Z$

Amaç: $\mathrm{Bu}$ çalışmada semptomatik akromioklaviküler (AK) eklem dejenerasyonu için artroskopik distal klavikula rezeksiyonu (DKR) uygulanan hastalarda eşlik eden eklem içi patolojiler yaş gruplarına göre değerlendirildi ve AK eklem dejenerasyonundan şüphelenilen hastalarda fizik muayene sırasında farklı yaş gruplarında hangi ek patolojilerin düşünülmesi gerektiği ortaya koyuldu.

Hastalar ve yöntemler: Çalışmaya Ocak 2006 - Aralık 2017 tarihleri arasında artroskopik DKR uygulanan ve ameliyat öncesi fizik muayenesinde AK eklem dejenerasyonu ile ilişkili en az bir klinik testi pozitif olan 156 hasta (55 erkek, 101 kadın; ort. yaş $57.2 \pm 10.0$ yıl; dağılım, 35-80 yıl) dahil edildi. Hastalar <50 yaş (grup 1), 50-65 yaş arası (grup 2) ve $>65$ yaş (grup 3) olmak üzere üç gruba ayrıldı. Eşlik eden eklem içi patolojiler farklı yaş gruplarına göre değerlendirildi ve gruplar arasında karşılaştırıldı.

Bulgular: Toplam 156 hastanın 117'sinde (\%75) eşlik eden eklem içi patoloji saptandı. Yaş arttıkça ek patoloji oranı arttı $(\mathrm{p}=0.002)$. Otuz yedi hastada (\%23.7) birden fazla eşlik eden eklem içi patoloji saptandı. Bu oran yaş arttıkça arttı $(\mathrm{p}=0.002)$. Ek patoloji olarak sadece superior labrum anterior posterior (SLAP) lezyonu olan hasta sayısı 33 (\%21.2) idi. Bu oran yaş arttıkça azaldı ( $\mathrm{p}=0.015)$. Grup 1'de, eşlik eden SLAP lezyonu oranı \% 44.1 idi.

Sonuç: Semptomatik AK eklem dejenerasyonuna eşlik eden eklem içi patolojilerin yüksek ortaya çıkış sıklığı, DKR planlanan hastalarda iyi sonuçlar alınması için dikkatli fizik muayene, detaylı görüntüleme ve artroskopik cerrahinin önemini artırmaktadır. Akromioklaviküler eklem dejenerasyonu ve eşlik eden SLAP lezyonlarının sıklığı özellikle daha genç hastalarda klinik muayeneler sırasında akılda tutulmalıdır.

Anahtar sözcükler: Akromioklaviküler eklem, artroskopi, distal klavikula rezeksiyonu, rotator manşet yırtığı, superior labrum anterior posterior lezyonu.

Received: August 14, 2018 Accepted: November 23, 2018

Correspondence: Mustafa Özer, MD. Necmettin Erbakan Üniversitesi Meram Tıp Fakültesi Ortopedi ve Travmatoloji Anabilim Dalı, 42080 Meram, Konya, Turkey. Tel: +90332-2236399 e-mail: mozer208@yahoo.com 
Acromioclavicular (AC) joint degeneration is a common condition that causes anterior-superior shoulder pain and restricts particularly the crossbody and overhead movements. Acromioclavicular joint degenerates with specific traumas, recurrent minor traumas, and aging. Particularly in elderly patients, most are asymptomatic, although radiologically there are AC joint degeneration findings. In asymptomatic patients, the prevalence of AC joint degeneration is reported to be between $48 \%$ and $82 \%$ in magnetic resonance imaging (MRI). ${ }^{[1-3]}$ In this context, even if AC joint degeneration exists radiologically in patients with complaints of shoulder pain, for appropriate treatment planning, it is important to reveal whether the symptoms are clinically associated with other pathologies (such as superior labrum anterior posterior [SLAP] lesions, subacromial impingement, rotator cuff tears, and instability) through a detailed physical examination.

In the presence of symptomatic $A C$ joint degeneration, distal clavicle resection (DCR) is planned in patients whose complaints persist despite an appropriate conservative treatment (non-steroidal anti-inflammatory drug therapy, activity modification, corticosteroid injections, immobilization, and physical therapy) and who have no instability or signs of infection in AC joints..$^{[1]}$

The complex anatomy of the shoulder can create difficulties in distinguishing symptoms that occur with different pathologies. Therefore, additional shoulder pathologies should be carefully evaluated, and differential diagnosis should be performed in patients with AC joint degeneration in radiological findings. In this study, we aimed to evaluate the accompanying intra-articular pathologies in patients who underwent arthroscopic DCR for symptomatic $A C$ joint degeneration based on age groups and to reveal which additional pathologies should be considered across different age groups during physical examination of patients suspected of AC joint degeneration.

\section{PATIENTS AND METHODS}

Preoperative physical examination reports and video recordings of shoulder arthroscopy procedures performed between January 2006 and December 2017 were obtained from the institutional database and retrospectively evaluated. The patients with glenohumeral (GH) arthritis, adhesive capsulitis, and massive rotator cuff tear, which could affect shoulder tests, were excluded from the study. Out of 3,239 evaluated patients, 156 (55 males, 101 females; mean age $57.2 \pm 10.0$ years; range, 35 to 80 years) who underwent arthroscopic DCR and had at least one clinical (cross-body adduction, O'Brien's active compression, $\mathrm{AC}$ joint tenderness) positive test for $\mathrm{AC}$ joint degeneration during the preoperative physical examination were included in the study. Demographic information, clinical symptoms, and early diagnosis of the patients were obtained from the hospital medical records. The study was conducted in accordance with the principles of the Declaration of Helsinki.

All arthroscopic surgeries were performed in semi-lateral (lateral decubitus) position, with the patients in $20^{\circ}-30^{\circ}$ posteriorly rotated position. The arm was in $45^{\circ}$ abduction and $15^{\circ}$ flexion under $10 \mathrm{lb}$ of longitudinal traction. The standard posterior portal was constituted as a viewing portal.
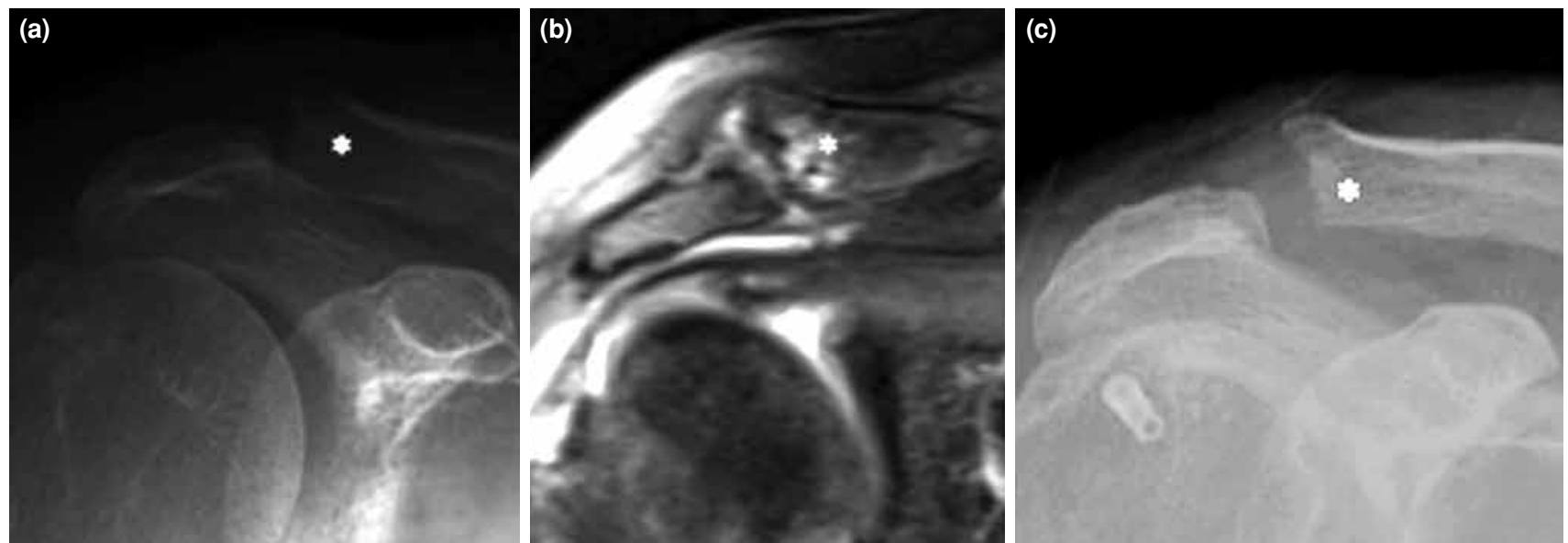

Figure 1. Right shoulder. (a, b) Preoperative anterior-posterior radiograph and coronal oblique magnetic resonance imaging, respectively, of acromioclavicular joint in a patient with symptomatic acromioclavicular joint degeneration. (c) Postoperative anterior-posterior radiograph of same patient. Asterix: Distal clavicle. 
The procedures were performed using $0.9 \%$ sodium chloride solution under $40 \mathrm{mmHg}$ of pressure. The intra-articular pathologies were intervened with the anterior working portal through the rotator interval. Then, the subacromial interval was taken care of and the pathologies in this region were intervened by the lateral working portal. After the location was determined by a spinal needle through the inferior $\mathrm{AC}$ joint, the anterior working portal planned for DCR was opened. Firstly, the inferior aspect of the joint was exposed by debriding soft tissues and inferior joint capsule with the aid of a radiofrequency probe or shaver. The inferior portion to be resected was decorticated with a burr placed in the anterior working portal and amount and borders of resection were determined (about 8-10 mm). The resection was initiated on the inferior surface, from the anterior toward the posterior, and continued considering the amount of resection determined.
Superior AC ligament, capsule, and posterior capsular ligament complex, which are important for AC joint stabilization, should be preserved after resection. After completion of the resection procedure, the posterosuperior region, where the most inadequate resection may be performed, must be reevaluated. The procedure was terminated after ensuring that symmetrical and adequate resection was performed, and osteophytes were cleaned (Figures 1-3).

The side of the surgery was right in 101 patients $(64.7 \%)$ and left in 55 patients $(35.3 \%)$. The patients were divided into three groups: those aged $<50$ years (group 1), 50-65 years (group 2), and $>65$ years (group 3). The demographic data of the groups are shown in Table 1.

On the digital video recordings, the intraarticular pathologies were determined as the presence of SLAP lesion, instability, and rotator
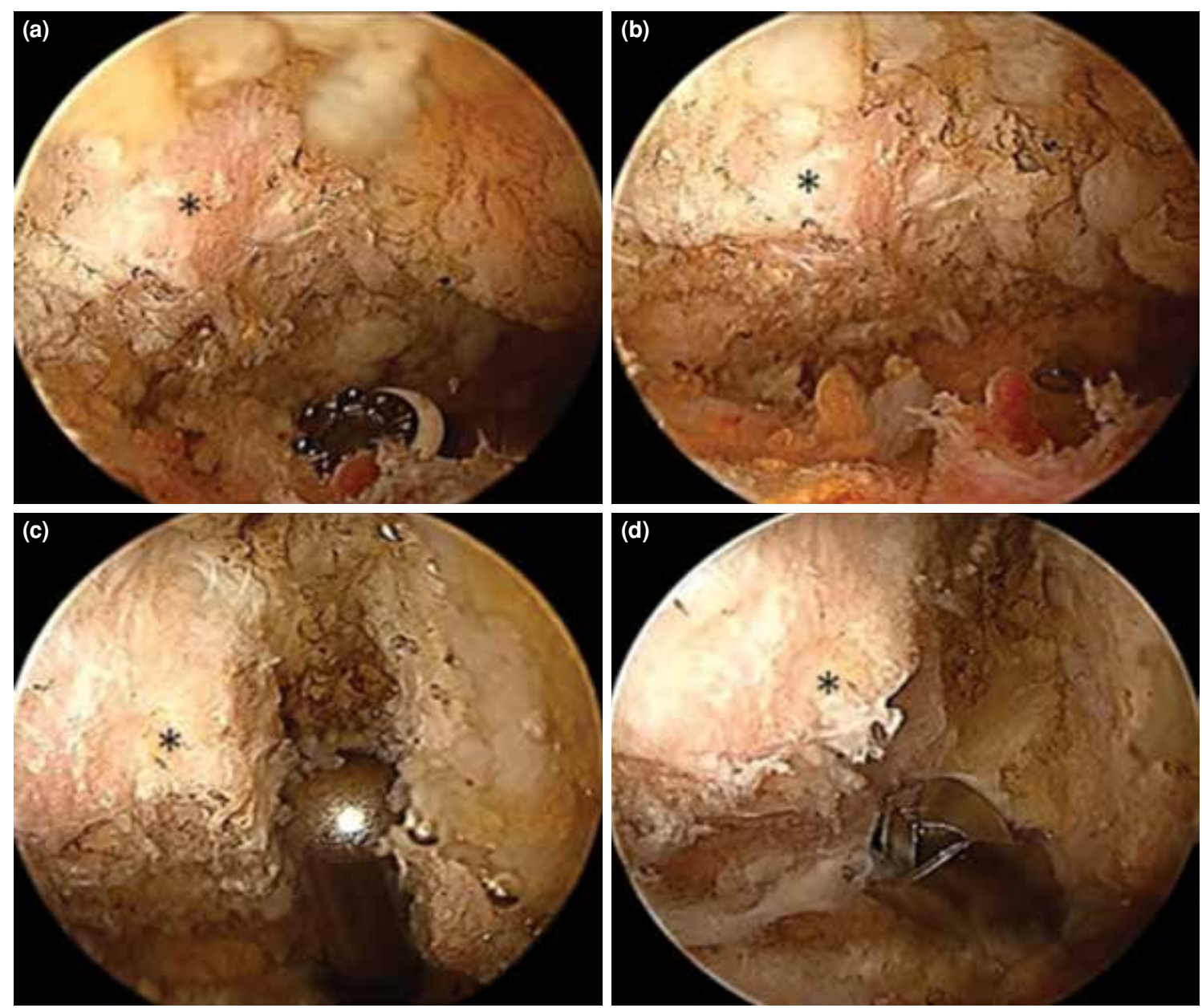

Figure 2. Right shoulder. (a) Acromioclavicular joint is exposed by debriding inferior aspect of acromioclavicular joint with radiofrequency. (b) Anterior portal for distal clavicle resection is determined with a spinal needle. (c) Soft tissues in acromioclavicular joint are debrided with radiofrequency. (d) Inferior aspect of distal clavicle is decorticated with a burr to determine resection margins. Asterix: Distal clavicle. 
cuff pathologies. The presence of subacromial compression, which is considered to be associated with inferior osteophytes in AC joint degeneration, was not included in the evaluation because it cannot be fully distinguished as a separate additional pathology. SLAP lesion was evaluated through the intra-articular examination as the presence of labrum separated from glenoid and the presence of unstable bicipitolabral complex. ${ }^{[4]}$ These additional pathologies were compared based on age groups and compared between groups.

\section{Statistical analysis}

Statistical analysis was performed using the IBM SPSS Version 21.0 software (IBM Corp., Armonk, NY, USA). Frequency, mean, and standard deviation values were calculated by descriptive statistical methods. Numeric variables were assessed using the Mann-Whitney U test. Dichotomous variables were assessed by crosstabs and Pearson's chi-square test or Fisher's exact test. For all comparisons, $p$ values
$<0.05$ (two-tailed) were considered to be statistically significant.

\section{RESULTS}

Concomitant intra-articular pathology was found in 117 (75\%) of 156 patients who underwent DCR due to symptomatic AC joint degeneration. This rate varied across the age groups while the additional pathology rate increased with increasing age $(\mathrm{p}=0.002)$. More than one concomitant intra-articular pathology was detected in 37 patients (23.7\%). This ratio also varied across the age groups, and the additional pathology rate increased with increasing age $(p=0.002)$. The number of patients with SLAP lesion as a single additional pathology was $33(21.2 \%)$. This ratio decreased with age $(p=0.015)$. The distribution of these ratios by groups is shown in Table 2 .

Superior labrum anterior posterior lesion was found in 56 patients (35.9\%). Although the frequency of SLAP lesions decreased with increasing age, the
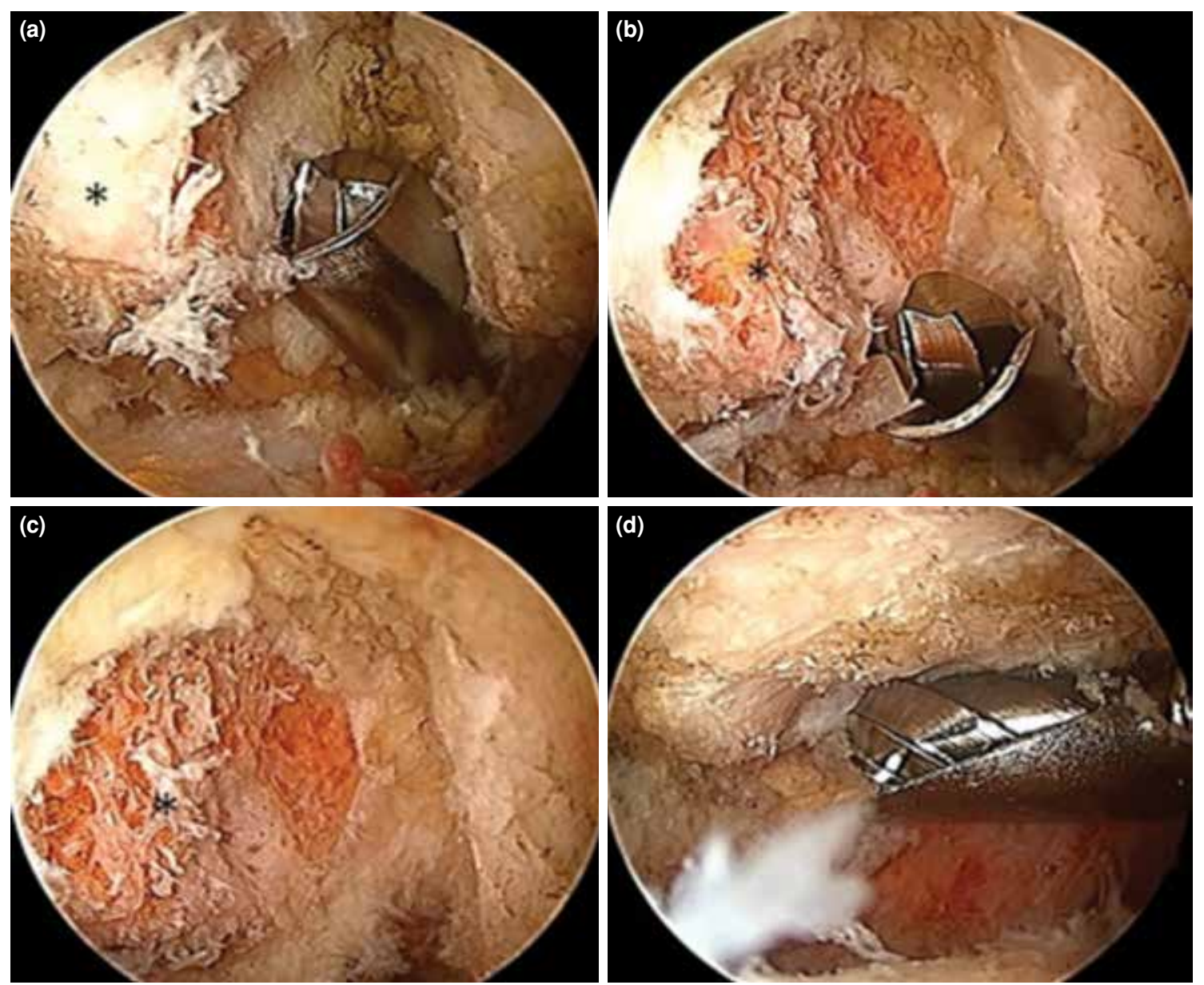

Figure 3. Right shoulder. (a-c) Distal clavicle resection is applied with a burr within specified boundaries. (d) Then, procedure is terminated following acromioplasty. Asterix: Distal clavicle. 


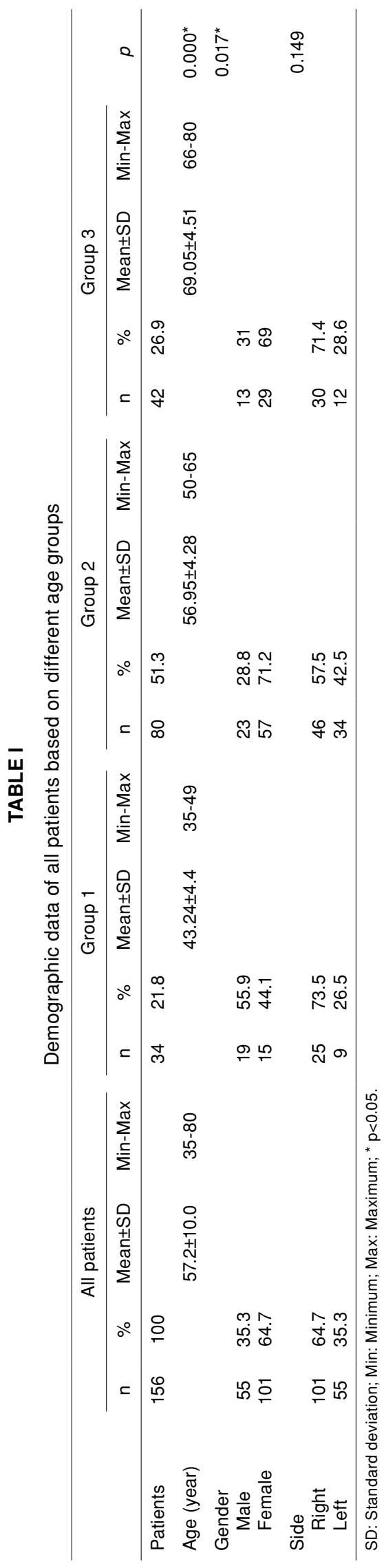

difference was not significant $(\mathrm{p}=0.479)$. In group 1 , SLAP lesions were mostly repaired $(p=0.006)$, while they were mostly treated with biceps tenodesis or tenotomy instead of repair in group $3(p=0.004)$. Glenohumeral instability was detected in three patients $(1.9 \%)$ as an additional intra-articular pathology. These three patients were in groups 1 and 2 .

Subscapularis tear was detected in 17 patients $(10.9 \%)$. As the age increased, the frequency of concomitant subscapularis tears increased, but the difference was not significant $(p=0.127)$. Supraspinatus tear was found in 72 patients (46.1\%). As the age increased, the concomitant supraspinatus tear rate increased $(\mathrm{p}=0.001) .79 .1 \%$ of supraspinatus tears were full-thickness. The distribution of concomitant intra-articular pathologies based on age groups is shown in Table 3.

\section{DISCUSSION}

In our study, the fact that concomitant intraarticular pathology was detected in $75 \%$ of all patients and in $92.9 \%$ of patients aged $>65$ years with symptomatic AC joint degeneration indicated that symptoms should be assessed not only by focusing on $\mathrm{AC}$ joint but also by considering additional pathologies, particularly in patients with AC joint degeneration in radiological findings. In our study, the most frequently observed concomitant intraarticular pathology in the group of patients aged $<50$ years with symptomatic AC joint degeneration was found to be SLAP lesion with a rate of $44.1 \%$ while it was rotator cuff tear with a rate of $76.2 \%$ in the group of patients aged $>65$ years. Although symptoms associated with $\mathrm{AC}$ joint degeneration and SLAP lesions can be distinguished by careful and detailed clinical tests, it should be considered during clinical examinations that both pathologies may be observed, particularly in young patients with AC joint degeneration.

It is difficult to clinically diagnose $\mathrm{AC}$ joint degeneration. Although pain is mostly described in the anterior and superior regions of the shoulder, it may also be felt on the anterolateral neck, deltoid, and trapezius. ${ }^{[5]}$ Because of the complex connections of the anatomical structures on the shoulder, patients may not generally define the actual pain location. Since similar symptoms can be observed in other shoulder pathologies, it is important to perform a careful physical examination using imaging methods and specific tests in differential diagnosis. ${ }^{[6]}$ Tests have limited diagnostic value because many clinical tests do not reveal the exact origin of pain. Among specific clinical tests, the 
TABLE II

Distribution of intra-articular pathologies accompanying symptomatic acromioclavicular joint degeneration for all patients based on age groups

\begin{tabular}{|c|c|c|c|c|c|c|c|c|c|}
\hline \multirow[b]{2}{*}{ Characteristics } & \multicolumn{2}{|c|}{ All patients } & \multicolumn{2}{|c|}{ Group 1} & \multicolumn{2}{|c|}{ Group 2} & \multicolumn{2}{|c|}{ Group 3} & \multirow[b]{2}{*}{$p$} \\
\hline & $\mathrm{n}$ & $\%$ & $n$ & $\%$ & $\mathrm{n}$ & $\%$ & $\mathrm{n}$ & $\%$ & \\
\hline Concomitant pathology & 117 & 75 & 20 & 58.8 & 58 & 72.5 & 39 & 92.9 & $0.002^{*}$ \\
\hline$>1$ concomitant pathology & 37 & 23.7 & 2 & 5.9 & 18 & 22.5 & 17 & 40.5 & $0.002^{*}$ \\
\hline Only SLAP lesion & 33 & 21.2 & 13 & 38.2 & 15 & 18.8 & 5 & 11.9 & $0.015^{*}$ \\
\hline
\end{tabular}

SLAP: Superior labrum anterior posterior; ${ }^{*} \mathrm{p}<0.05$.

TABLE III

Distribution of intra-articular pathologies accompanying symptomatic acromioclavicular joint degeneration for all patients based on age groups

\begin{tabular}{|c|c|c|c|c|c|c|c|c|c|}
\hline \multirow[b]{2}{*}{ Characteristics } & \multicolumn{2}{|c|}{ All patients } & \multicolumn{2}{|c|}{ Group 1} & \multicolumn{2}{|c|}{ Group 2} & \multicolumn{2}{|c|}{ Group 3} & \multirow[b]{2}{*}{$p$} \\
\hline & $\mathrm{n}$ & $\%$ & $\mathrm{n}$ & $\%$ & $\mathrm{n}$ & $\%$ & $\mathrm{n}$ & $\%$ & \\
\hline Glenohumeral instability & 3 & 1.9 & 1 & 2.9 & 2 & 2.5 & - & - & \\
\hline SLAP lesions & 56 & 35.9 & 15 & 44.1 & 28 & 35 & 13 & 31 & 0.479 \\
\hline SLAP repair & 37 & 23.7 & 14 & 41.2 & 19 & 23.8 & 4 & 9.5 & $0.006^{*}$ \\
\hline Biceps tenodesis/tenotomy & 36 & 23.1 & 2 & 5.9 & 18 & 22.5 & 16 & 38.1 & $0.004^{*}$ \\
\hline Subscapularis tears & 17 & 10.9 & 2 & 5.9 & 7 & 8.8 & 8 & 19 & 0.127 \\
\hline Supraspinatus tears & 72 & 46.1 & 5 & 14.7 & 35 & 43.8 & 32 & 76.2 & $0.001^{*}$ \\
\hline Partial (bursal side) & 10 & 6.4 & - & - & 6 & 7.5 & 4 & 9.5 & \\
\hline Partial (articular side) & 5 & 3.2 & 2 & 5.9 & 3 & 3.8 & - & - & \\
\hline Full-thickness & 57 & 36.5 & 3 & 8.8 & 26 & 32.5 & 28 & 66.7 & \\
\hline
\end{tabular}

SLAP: Superior labrum anterior posterior; ${ }^{*} p<0.05$.

most sensitive one for $\mathrm{AC}$ joint degeneration was reported to be the cross-body adduction test with $77 \%$ sensitivity, and the most specific one was reported to be the O'Brien's active compression test with $95 \%$ specificity. ${ }^{[6,7]}$ In O'Brien's active compression test, the shoulder was put in a $90^{\circ}$ forward flexion and $10^{\circ}$ adduction position. First, the patient resisted shoulder flexion when the limb was in the maximum internal rotation. Then, resisted shoulder flexion was repeated by taking the shoulder into maximum supination. While the pain occurring in the maximal internal rotation was assessed in favor of SLAP lesion, the pain in the maximal supination was evaluated in favor of AC joint degeneration. Clinical tests should be performed considering that SLAP lesions may accompany symptomatic AC joint degeneration particularly in younger patients. Difficulties in diagnosing SLAP lesions in conventional MRI and the fact that the reported incidence of $A C$ joint degeneration in MRI of asymptomatic individuals reaches up to $82 \%$ raise the importance of this test. ${ }^{[2]}$
It was revealed in pre- and post-evaluations of $\mathrm{AC}$ joint injections that $\mathrm{AC}$ joint degeneration significantly affects orthopedic shoulder tests. ${ }^{[8]}$ Although persisted pain following the administration of local anesthetic injection into AC joint can lead us to another shoulder pathology, we should consider that $\mathrm{AC}$ joint degeneration may be an addition to other pathologies, particularly in patients with reduced pain, albeit minimally. As in impingement syndrome, diagnostic $\mathrm{AC}$ joint injection is reported as the gold standard in the diagnosis of $\mathrm{AC}$ joint degeneration..$^{[9,10]}$ In the literature, it was reported that AC joint injection should be ultrasound-guided as in the GH joint since the accuracy rate in blind injections is $40-72 \% .{ }^{[11-15]}$

Resection can be performed with a direct view of the joint space with open DCR; however, AC joint instability and persistent pain associated with poor functional outcome can occur due to damage in deltoid fascia, superior AC ligament, and capsule. ${ }^{[16,17]}$ Better results can be achieved by preserving these structures with arthroscopic DCR. ${ }^{[16,17]}$ Glenohumeral 
and subacromial arthroscopy are of great importance for the detection and treatment of pathologies associated with AC joint degeneration. Brown et al. ${ }^{[18]}$ reported pathologies associated with symptomatic AC joint degeneration as follows: rotator cuff tear at $81 \%$, labral tear at $33 \%$, and biceps tendon pathology at $22 \%$. They reported concomitant labral tear to be $42 \%$ and concomitant rotator cuff tear as $65 \%$ in patients aged $<50$ years with AC joint degeneration, while they reported concomitant labral tear as $29 \%$ and concomitant rotator cuff tear as $86 \%$ in patients aged $>50$ years. In the literature, apart from this study, there is no other study on concomitant pathologies associated with symptomatic AC joint degeneration. Although additional pathology rate associated with labrum and biceps tendon in this study was similar to that of our study, we found the rate of additional rotator cuff tear to be lower than that of this study. This may be because the patient group with $\mathrm{GH}$ arthritis, which is excluded from our study since it could cause confusion during the examination, was included in that study. Unlike that study, we separately evaluated subscapularis tears and SLAP lesions, which are very important for shoulder biomechanics. Brown et al. ${ }^{[18]}$ found the rate of concomitant pathologies accompanying symptomatic AC joint degeneration as $97.7 \%$, whereas we found it as $75 \%$.

Berg and Ciullo ${ }^{[19]}$ detected SLAP lesions following arthroscopy performed in 15 (75\%) of 20 patients who had persistent pain after DCR. In $13(86 \%)$ of these 15 patients, DCR was performed for $\mathrm{AC}$ joint degeneration and there was a trauma history in 14 patients. The mean age of these patients was reported to be 37 (range, 20-50) years. In conclusion, it was reported in the study that SLAP lesions should be ruled out with GH arthroscopy first in young patients with trauma history in order to avoid unnecessary DCR. In our study, the rate of SLAP lesions accompanying symptomatic AC joint degeneration in young patients was $44.1 \%$, indicating that DCR may also be necessary for patients with SLAP lesions. Specific traumas, recurrent microtraumas, and overhead activities may play a role in the etiology of both pathologies.

There are several limitations of the current study. First, although the data were collected prospectively, the study was designed retrospectively. In the prospective studies to be planned in the future, co-evaluation of arthroscopic findings, particularly with specific clinical tests, will be more informative about the points to be noted across different age groups in the preoperative period. Another limitation is that the impact of additional pathologies on clinical outcome was not assessed in the postoperative follow-up based on age groups.

In conclusion, the frequency of intra-articular joint pathologies accompanying symptomatic $A C$ joint degeneration raises the importance of careful physical examination, detailed imaging, and arthroscopic surgery for the best outcomes in patients scheduled for DCR. Acromioclavicular joint degeneration should be certainly taken into consideration in the evaluation of shoulder pathologies including rotator cuff tears, SLAP lesions, and GH instability. The frequency of AC joint degeneration and concomitant SLAP lesions, particularly in younger patients, should be considered during clinical examinations.

\section{Declaration of conflicting interests}

The authors declared no conflicts of interest with respect to the authorship and/or publication of this article.

\section{Funding}

The authors received no financial support for the research and/or authorship of this article.

\section{REFERENCES}

1. Docimo S Jr, Kornitsky D, Futterman B, Elkowitz DE. Surgical treatment for acromioclavicular joint osteoarthritis: patient selection, surgical options, complications, and outcome. Curr Rev Musculoskelet Med 2008;1:154-60.

2. Stein BE, Wiater JM, Pfaff HC, Bigliani LU, Levine WN. Detection of acromioclavicular joint pathology in asymptomatic shoulders with magnetic resonance imaging. J Shoulder Elbow Surg 2001;10:204-8.

3. Needell SD, Zlatkin MB, Sher JS, Murphy BJ, Uribe JW. MR imaging of the rotator cuff: peritendinous and bone abnormalities in an asymptomatic population. AJR Am J Roentgenol 1996;166:863-7.

4. Snyder SJ, Karzel RP, Del Pizzo W, Ferkel RD, Friedman MJ. SLAP lesions of the shoulder. Arthroscopy 1990;6:274-9.

5. Mazzocca AD, Arciero RA, Bicos J. Evaluation and treatment of acromioclavicular joint injuries. Am J Sports Med 2007;35:316-29.

6. Chronopoulos E, Kim TK, Park HB, Ashenbrenner D, McFarland EG. Diagnostic value of physical tests for isolated chronic acromioclavicular lesions. Am J Sports Med 2004;32:655-61.

7. Mall NA, Foley E, Chalmers PN, Cole BJ, Romeo AA, Bach BR Jr. Degenerative joint disease of the acromioclavicular joint: a review. Am J Sports Med 2013;41:2684-92.

8. Ulaşlı AM, Erkeç S, Uyar S, Nacır B, Yılmaz Ö, Erdem HR. The effect of acromioclavicular joint degeneration on orthopedic shoulder tests. Eklem Hastalik Cerrahisi 2013;24:77-81.

9. Walton J, Mahajan S, Paxinos A, Marshall J, Bryant C, Shnier $\mathrm{R}$, et al. Diagnostic values of tests for acromioclavicular joint pain. J Bone Joint Surg [Am] 2004;86:807-12. 
10. Yılmaz C, Gölpınar A, Öztuna V. The efficacy of subacromial corticosteroid injections in impingement syndrome. Eklem. Hastalik Cerrahisi 2008;19:24-6.

11. Krill MK, Rosas S, Kwon K, Dakkak A, Nwachukwu $\mathrm{BU}$, McCormick F. A concise evidence-based physical examination for diagnosis of acromioclavicular joint pathology: a systematic review. Phys Sportsmed 2018;46:98-104.

12. Aly AR, Rajasekaran S, Ashworth N. Ultrasound-guided shoulder girdle injections are more accurate and more effective than landmark-guided injections: a systematic review and meta-analysis. Br J Sports Med 2015;49:1042-9.

13. Borbas P, Kraus T, Clement H, Grechenig S, Weinberg AM, Heidari N. The influence of ultrasound guidance in the rate of success of acromioclavicular joint injection: an experimental study on human cadavers. J Shoulder Elbow Surg 2012;21:1694-7.

14. Ağırman M, Leblebicier MA, Durmuş O, Saral İ,
Gündüz $\mathrm{OH}$. Should we continue to administer blind shoulder injections? Eklem Hastalik Cerrahisi 2016;27:29-33.

15. Ketola S, Lehtinen J, Rousi T, Nissinen M, Huhtala $H$, Arnala I. Which patients do not recover from shoulder impingement syndrome, either with operative treatment or with nonoperative treatment? Acta Orthop 2015;86:641-6.

16. Amirtharaj MJ, Wang D, McGraw MH, Camp CL, Degen RA, Dines DM, et al. Trends in the surgical management of acromioclavicular joint arthritis among board-eligible US orthopaedic surgeons. Arthroscopy 2018;34:1799-805.

17. Chronopoulos E, Gill HS, Freehill MT, Petersen SA, McFarland EG. Complications after open distal clavicle excision. Clin Orthop Relat Res 2008;466:646-51.

18. Brown JN, Roberts SN, Hayes MG, Sales AD. Shoulder pathology associated with symptomatic acromioclavicular joint degeneration. J Shoulder Elbow Surg 2000;9:173-6.

19. Berg EE, Ciullo JV. The SLAP lesion: a cause of failure after distal clavicle resection. Arthroscopy 1997;13:85-9. 